\title{
NGOs in Ukraine: Growing amid growing concern
}

\author{
Roger A. Ritvo \\ Auburn University Montgomery, Montgomery, Alabama, USA 36124-4023. \\ Accepted 02 January, 2014
}

\begin{abstract}
This article focuses on the development of non-governmental organizations (NGOs) in the post-Soviet country of Ukraine. Since the Soviet Union collapsed only 2 decades ago, civil society organizations have grown numerically, but are they making a difference in the lives of the citizens? Data from other former Soviet states show mixed results. Ukraine has a legacy of mistrust and distrust of NGOs; as it looks to engage with Western, industrialized countries and the global economy, there are both internal and external pressures for and against more democratic institutions. The hundreds of thousands who demonstrated in December 2013 and early 2014 show that the direction of this emerging democratic state is still in flux. Will Ukraine continue to re-align with the Russian influences to its east or will its government increase connections with the European Union and other western political and economic institutions? These decisions will have an impact on NGOs.
\end{abstract}

Key words: Civil society, competencies, growth, leadership, development.

\section{INTRODUCTION}

Former Secretary of State Hillary Clinton stressed the importance of developing civil societies and the organizations needed to mediate between what governments can and cannot (will and will not?) offer in the way of programs, services and guarantees of human and civil rights. Based on research and scholarship on the emerging roles of non-governmental organizations (NGOs) in post-Soviet countries, there seems to be patterns to the successes and problems encountered in various societies.

\section{The 6 competencies for effective NGO leadership}

A major conceptual model defines the 6 governing and leadership competencies of effective NGO leaderships: strategic, educational, political, interpersonal, analytical and contextual competencies. This model has formed the basis for several books and numerous articles (Holland and Ritvo, 2008). Of immediate relevance to the turmoil in Ukraine at the end of 2013 and 2014 are the challenges to strategic competencies. For NGOs to be successful they must make decisions about which programs and services to offer, using limited financial and staff resources where they can have the most (or at least major) impact. This requires using available information to choose between competing needs. Yet, in a dynamic, threatening and perhaps hostile environment, will the public accept NGO programs? Will the government allow the NGOs to operate without interference? Even in stable times, NGOs have enough trouble raising funds to offer services.

Several models that have characterized NGOs in two post-Soviet societies (Azerbaijan and the Republic of Georgia) involve a rather rapid growth of the nonprofit sector numerically. But this has not been augmented by an increase in the public's awareness of, or trust in, these NGOs. Some NGOs have strong government support, especially those focused on business and economic development. Others (such as those with transparency, human rights, press freedom and grass-roots organizing as their mission) raise suspicion. Since Ukraine has less 
than a single generation of experience as an independent country, these obstacles may also be having a negative impact (Miroslav, 2000).

There are major impediments to developing and operating successful NGOs in Ukraine. Pastukhova and Mykhailiuk (2012) note the 'Hurdles for NGOs": "It is much more complicated in Ukraine to set up an NGO than a business venture. ... Unlike all European and some $\mathrm{CIS}$ countries, in Ukraine only its citizens have the right to create NGOs. [As a result] in Ukraine, $17 \%$ of the population belongs to various associations, but a mere $2 \%$ are really active"

One indirect way to gauge public support for government programs and policies is the general attitude of the population to paying their taxes. Using the hypothesis that "Tax evasion will be more acceptable if the system is perceived as being unfair or if the government engages in human rights abuses", Nasadyuk and McGee (2007) showed this to be the case; people did not trust the Ukrainian government and stopped paying their fair share. But this lack of support does not imply that the same people would or do view NGOs in a favorable light.

Many NGOs are funded by international philanthropy such as the Soros Foundation, USAID, the United Nations, numerous foreign governments as well as recognized international NGOs such as Red Cross, National Endowment for Democracy, World Bank, and Europe without Borders. These funds often support infrastructure such as capacity building, training, computers, internet access, improved record maintenance and documenting financial transactions to avoid corruption. "At some point though, the civil society starts questioning the effectiveness of such training and technical assistance. It is indeed very hard to evaluate. The Western-ideals of goal oriented efficiency may not be the answer to all problems. If they want to survive, advocacy NGOs in the third world countries would have to continue receiving their funding from foreign donors" (Pidgornvy, 2012).

Holmov (2011) notes that some NGOs "are so "big" they are completely and utterly disconnected from the Ukrainian public to the point that they have never heard of them, are suspicious of their motives, distinctly fall into the "others" interfering in "our" structures, not for "our" benefit but "theirs." This reflects the negative attitudes toward NGOs found in other post-Soviet societies. This articles stresses that many Ukrainians are "highly suspicious of the motivations of the financiers behind many of the NGOs, particularly the private financiers such as Mr. Soros." Clearly, there are mixed opinions of NGOs in Ukraine (Wilson, 2009; Stewart, 2009).

A contracted report for the US Agency for International Development, reached the overriding conclusion that "the most obvious weaknesses of support from all donors involved in the NGO development process has been a lack of attention to high professional standards of good governance, ethics, and transparency; and a failure to focus on the attraction of local, financial, human, and other resources. One of the most important consequences of these two lapses is a failure to capitalize on the domino effect of demonstration projects, one of the basic concepts of building a civil society through support for grassroots NGOs" (ARD, Inc. 2001, p. i).

"Globalization today is affecting the often-blurred relationships among Governments, Corporates, and NonGovernmental Organizations (NGOs) in developing countries. [It] seems to be encouraging ... collaborations or partnerships among the three sectors-especially corporates and NGOs, facilitating the advancement of each of their fundamental goals and objectives." NGOs benefit in several important ways: (a) Mission-driven NGOs can expand programs and services to their stakeholders; (b) they gain access to needed resources; and (c) NGO staff can learn needed skills through targeted technical assistance programs. Corporations benefit as well. (a) They reap the rewards from the act and appearance of outreach and corporate social responsibility initiatives. (b) In some countries, philanthropy can be a tax-deductible expense and a sound business practice at the same time. (c) Some firms may choose to partner with an international NGO to gain a foothold in an expanding market (Moody, 2011).

The Mim-Kiev Business School and Institute (2003) actively supports the ideal that "ethical standards must be set to promote sustainable business development." But, in 2003, an article on its website had the provocative title of Business Ethics: Is It Still a Luxury in Ukraine? A summary noted that "in Ukraine for a long time ethics was regarded as an expensive toy for a successful business."

The key to NGO-corporate partnerships is that they develop mutual trust, shared commitment to both the short and long-term aspirations of the project(s) and perhaps most important, a shared vision. These results are more likely to become reality when roles, responsibilities and accountabilities are negotiated and defined in writing at the beginning of any partnership or collaborative action. Funding often requires assessments to document activities, progress, successes and areas that need improvement. The complexity of corporate-NGO connections is illustrated clearly in the following paradox. "NGOs do not have a single type of relationship with business. ... Big companies increasingly seek to have "dialogue" with critical NGOs and to co-opt them through grants, 'partnerships,' 'multi-stakeholder dialogues and other means. While leading public relations firms pioneer ever-new forms of 'proactive' business policies towards NGOs, global justice movement NGOs pioneer ever-new forms of criticism and public accountability for private firms" (Global Policy Forum, undated). While NGOs receive much-needed technical assistance and financial support, corporations get favorable publicity and can take (some or a lot of) credit and benefit from program 
successes.

According to the US Department of State, citing the 2012 Ukrainian Unified State Register of Companies and Organizations, the "71,767 public associations and 13,475 charitable foundations and organizations ... include international, national, and local organizations, as well as their branch offices, sub-offices, and separate units that are not registered as separate legal entities. This represents an increase of 6 and $5 \%$ respectively since the beginning of 2011" (USAID, 2012). The US AID 2012 Annual Report on Ukraine summarizes the current situation follows: "Limited funding opportunities and a weak economy continue to hinder CSO activities. Inadequate resources, uncompetitive salaries, and low public motivation weakened CSOs' human resources, despite the various institutional capacity building programs supported by the donor community."

The report to USAID acknowledged a basic misunderstanding of role of NGOs: 'Many local officials believe that the primary role of NGOs is to replace government services and roles." This creates the tension, mistrust and suspicions that remain today (ARD, 2001). Indeed, while most NGOs strive to focus on their missions, it is almost impossible in Ukraine to avoid becoming part of the new society, its emerging freedoms, challenges, aspirations and problems. "All the more reason, then, to raise the alarm by publicizing the drift toward authoritarianism on the Putin model that seems to be accelerating in Ukraine under President Yanukovych. That might be a first step toward energizing the kind of Western nongovernmental support for democracy in Ukraine that was crucial to the success of the revolutions of 1989" (Weigel, 2011). This prophetic caution was written two years before President Yanukovych decided at the last moment not to sign a cooperative agreement with the EU; instead he agreed to a large financial infusion and lower energy prices offered by Russia and Putin.

Given the already rather low level of public participation and support for NGOs in Ukraine, the 3-5 year future of these basic building blocks of civil society seems bleak.
www.amnesty.org/en/library/asset/EUR50/005/2013/en/a3a6cc3bf059-4954-b9b7-f2e1c81fd721/eur500052013en.pdf.

ARD, Inc (2001). Assessment of Non-governmental and Civil Society Organizations in Ukraine and Moldova. 7/26/2001. ARD, Inc.; 159 Bank Street, Third Floor; Burlington, Vermont 05401.

Global Policy Forum (undated). Accessed September 22, 2013.

Holland T, Ritvo RA (2008). Nonprofit Organizations: Principles and Practices. New York: Columbia University Press.

Holmov $N$ (2011). Yet another look at NGOs in Ukraine. www.odessatalk.com, October 10, 2011. Accessed May 29, 2013. www.odessatalk.com/2011/10/yet-another-look-at-ngos-in-ukraine.

Mim-Kiev Business School and Institute (2003). Business Ethics: Is It Still a Luxury in Ukraine? October 16, 2003. www.mim.kiev.ua/ en/press/news/2003/322/ Accessed September 16, 2013.

Miroslav R (2000). Civil Society in Ukraine: Focus on the Third Sector. Washington, DC: World Bank Informal Paper.

Moody's (2011). Corporate-Ngo Partnerships in Social Development: Issues and Concerns. Moody's, March 2011.

Nasadyuk I, McGee RW (2007). Ethics and Tax Evasion in Ukraine: An Empirical Study. Miami Shores, FL: Barry University, Andreas School of Business Working Paper Series, April 2007, p.9.

Pastukhova A, Mykhailiuk Y (2012). "Hurdles for NGOs: Ukraine's public organizations are hampered by outdated legislation and red tape," The Ukrainian Week, January 27, $2012 . \quad$ http:// www.ukrainianweek.com/Politics/22832; Accessed December 17, 2013

Pidgornvy V (2012). NGOs in the Developing Countries - Evolution or Devolution? April 10, 2012. http://wnu-ukraine.com/magazine/ articles/?id=1573; Accessed May 28, 2013.

The Role of Government and NGOs in the System of Ethno-political Management in Ukraine. http://www.slideshare.net/yevtukh/the-roleof-government-and-ngo. Accessed July 11, 2013.

Stewart, Susan (2009). "NGO Development in Ukraine since the Orange Revolution," in Juliane Besters-Dilger (ed.) Ukraine on its Way to Europe: Interim Results of the Orange Revolution, Peter Lang Verlag, Frankfurt a.M. et.al. pp. 177-194.

Transparency.org. http://transparency.org/country\#UKR.

United Nations (2011). Stigma of Human Trafficking Victims. September 30, 2011.

USAID (2012). 2012 CSO Sustainability Index: Ukraine. The 2012 CSO Sustainability Index for Central; and Eastern Europe and Eurasia. (Accessed September 24, 2013).

http://www.usaid.gov/sites/default/files/documents/1863/UKR.pdf and

http://www.usaid.gov/europe-eurasia-civil-society/cso-sustainability2012/ukraine

Weigel G (2011). Troubles in Ukraine. National Review Online. Accessed September 13, 2013. www.eppc.org/publications/troublesin-ukraine/.

Wilson A (2009). The Ukrainians: Unexpected Nation. New Haven: Yale University Press.

\section{REFERENCES}

Amnesty International (2013). Nothing to be Proud of: Discrimination against LGBTI people in Ukraine. Index: EUR 50/005/2013 Amnesty International May 2013 Accessed July 10, 2013. 